\title{
How Do Nature-Based Solutions Improve Environmental and Socio-Economic Resilience to Achieve the Sustainable Development Goals? Reforestation and Afforestation Cases from the Republic of Korea
}

\author{
Gaeun Kim $^{1}$, Jiwon Kim ${ }^{1} \mathbb{D}$, Youngjin Ko ${ }^{1}$, Olebogeng Thelma G. Eyman ${ }^{1}$, Sarwat Chowdhury ${ }^{2} \mathbb{D}$, \\ Julie Adiwal $^{2}$, Wookyun Lee ${ }^{1}$ (D) and Yowhan Son ${ }^{1, *}$ \\ 1 Department of Environmental Science and Ecological Engineering, Korea University, Seoul 02841, Korea; \\ marine1031@korea.ac.kr (G.K.); jiwonandonly@korea.ac.kr (J.K.); ko871004@gmail.com (Y.K.); \\ 2020021591@korea.ac.kr (O.T.G.E.); leewk@korea.ac.kr (W.L.) \\ 2 United Nations Development Programme Seoul Policy Centre, Seoul 02841, Korea; \\ sarwat.chowdhury@undp.org (S.C.); julie.adiwal@undp.org (J.A.) \\ check for \\ updates \\ * Correspondence: yson@korea.ac.kr; Tel.: +82-02-3290-3015
}

Citation: Kim, G.; Kim, J.; Ko, Y.; Eyman, O.T.G.; Chowdhury, S.; Adiwal, J.; Lee, W.; Son, Y. How Do Nature-Based Solutions Improve Environmental and Socio-Economic Resilience to Achieve the Sustainable Development Goals? Reforestation and Afforestation Cases from the Republic of Korea. Sustainability 2021, 13, 12171. https://doi.org/10.3390/ su132112171

Academic Editors:

Raúl Romero-Calcerrada,

Javier Cabello,

Manuel Pacheco-Romero and Koldo Trapaga Monchet

Received: 1 October 2021

Accepted: 2 November 2021

Published: 4 November 2021

Publisher's Note: MDPI stays neutral with regard to jurisdictional claims in published maps and institutional affiliations.

Copyright: (C) 2021 by the authors. Licensee MDPI, Basel, Switzerland This article is an open access article distributed under the terms and conditions of the Creative Commons Attribution (CC BY) license (https:// creativecommons.org/licenses/by/ $4.0 /)$

\begin{abstract}
Industrial and technological development have contributed significantly to causing environmental crises, such as climate change and land degradation. To address these environmental challenges, nature-based solutions (NBS) have gained increased attention over conventional technical responses. This study derived conceptual linkages from NBS application to resilience promotion, and subsequently, to the achievement of sustainable development goals (SDGs). The study was conducted to reveal that NBS activities are an essential approach that determines the balance between human development and nature conservation. In this paper, we compare four case studies, one domestic reforestation project and three international afforestation projects, all of which had forest-related NBS experiences and were conducted by the Republic of Korea. All four projects were found to have an impact on environmental and socio-economic resilience. These impacts were qualitatively assessed through resilience indicator evaluations. Subsequently, the resilience indicators were matched with the targets of the SDGs. NBS initiatives designed to include various natural and social elements promoted the resilience of ecosystems and society and address a broader spectrum of SDGs. Further efforts to establish region-specific promotional models, identify resilience indicators, and collect scientific data are recommended for quantitatively assessing the NBS initiatives.
\end{abstract}

Keywords: nature-based solutions; resilience; sustainable development goals; afforestation; reforestation; climate change; desertification; land degradation

\section{Introduction}

Rapid industrialization has caused a global environmental crisis, which in turn has produced rebound effects by threatening human society. The expansion of arid areas and degraded lands has not only caused an environmental crisis but also brought about social and economic crises that demand immediate solutions to harmonize human development and nature conservation and look further than the conventional technological innovations used to address these issues [1]. The need for fundamental prevention and mitigation of these problems has encouraged us to go beyond technological responses. For instance, desertification can be prevented by creating an ecosystem in arid regions, and such preventive measures eliminate the need for technical solutions. The concept of nature-based solutions (NBS) has emerged in this context. While there are always debates on the issues of the trade-off between NBS and other technical solutions, however, this paper focuses on NBS instead of other solutions to derive the implications of NBS. According to the International Union for Conservation of Nature (IUCN), NBS is described as "actions to 
protect, sustainably manage, and restore natural or modified ecosystems that address societal challenges effectively and adaptively, simultaneously providing human well-being and biodiversity benefits" [1]. Based on its holistic characteristics, NBS is now emerging as a global consensus and practical guideline for the international community, by expanding the scope of its application. Why and how does NBS function to address these urgent socio-economic and environmental problems? The reason for this is the contribution of NBS to resilience enhancement [2,3].

Resilience is defined as the ability of a system to maintain its function and structure against external perturbations [4-6]. The perturbations that originate outside of a system are challenges, threats, and sometimes, uncertainties that harm the integrity of the system [4]. A system covers a variety of fields that it can be a natural ecosystem, society, or economic system $[5,6]$. The concept of resilience is used in a broad range of academic fields, including ecology, psychology, and engineering, with each discipline presenting distinct definitions [7-9]. This study addressed two types of resilience, environmental and socio-economic resilience, to include the ecological and social aspects that sustain human livelihoods. According to Holling, environmental resilience is the capacity of a system to withstand shock and maintain critical structures and functions [10]. Adger refers to social resilience as the capacity of communities to cope with external stresses resulting from social, political, and environmental changes [11]. Based on these two definitions, this study attempted to expand Adger's definition of "social resilience" and use the term "socio-economic resilience" because both social and economic aspects represent community resilience [12,13].

NBS can assist in achieving the continuity of a system by reducing the risk factors of the system or enhancing the ability of the system to respond to external shocks. For example, in arid regions suffering from desertification, NBS act as a fundamental solution by transforming deserts into grasslands, shrublands, and forests through vegetation establishment, which ultimately reduces the risk factors of the ecosystems. Multiple studies provide evidence that NBS activities contribute to resilience enhancement [2,3]. Thus, in this study, the elements related to the system's continuity were considered as resilience indicators. We followed the narrative of the concept that strengthening these indicators enhances the resilience of the system, thereby making the system sustainable.

Achieving environmental and social sustainability can further be aligned with the sustainable development goals (SDGs) of the global 2030 agenda that aims for global transformation. Seventeen SDGs were developed to respond to environmental and social issues, such as climate change and poverty. NBS implementation can assist in achieving these SDGs by enhancing resilience [2,14]. Several cases exploring NBS for building resilience in cities, rural areas, and coastal regions were previously studied [2], and according to Martín, several SDGs can be achieved through NBS implementation by promoting the delivery of ecosystem services that generate environmental, societal, and economic cobenefits [14]. Therefore, SDGs can be internationally recognized as achievements and desirable milestones for NBS actions. The logical evolution that resilience contributes to sustainable development initiated with the development of the concept of resilience $[15,16]$. For instance, Handmer and Dovers distinguished systemic resilience types, including resistance to change, decreasing the pace of change, and creating a new adaptable system that consequently result in ecological sustainability [16]. The most recent study by Acharya et al. also proposes the connections between NBS and resilience based on case studies and further suggests the need for transformative approaches to create resilience to achieve SDGs that reflect the rapidly changing contemporary natural and social systems [17].

Based on the previous literature, we included more cases and profound implications on such environmental and social connections. These connections were within the scope of NBS experiences, which were conducted by the Republic of Korea (Korea), with emphasis on the forest sector. Understanding the NBS experiences of Korea is important because Korea is one of only four countries that succeeded in forest rehabilitation after World War II [18]. According to a report by the Food and Agriculture Organization, the reforestation 
rate per ha of Korea between 1990 and 2015 was 196\%, which is the highest increase rate in the Asia-Pacific region, and the highest among the countries falling within the scope of the Organization for Economic and Cooperation Development and G20 [19]. One of the reasons for the successful reforestation in Korea was the active engagement of residents, aided by strong governmental authorities. Additionally, establishing 10-year plans to periodically review and revise the forest policies and management, and implementing energy policies to replace household fuels from wood to fossil fuels led to the success of the reforestation. Reforestation was a common goal that encompasses the fields of politics, society, and the economy. Based on these successful reforestation experiences, Korea is currently conducting multiple afforestation-related official development assistance (ODA) initiatives in countries worldwide.

This study attempts to share Korea's experiences of utilizing the NBS concept and analyze the sequential connectivity between NBS and the resilience of an ecosystem and society, and ultimately the association with the universal standards of human well-being, the SDGs. The cases are divided into two sections comprising one domestic reforestation project and three international afforestation projects. The Korean government led the domestic reforestation project in the late 1900s. The gained experience served as the basis to conduct overseas afforestation projects in three countries, China, Mongolia, and Kazakhstan, all of which received ODA from the Korean government. In China, the Korea-China Amity Great Green Wall Project began in 2002 and was managed by the Future Forest, a Korean non-governmental organization (NGO). In Mongolia, afforestation projects spearheaded by the Green Asia Network (GAN), another Korean NGO, have been underway since the early 2000s. In Kazakhstan, the Korea Forest Service (KFS) rehabilitated the dry and dusty Aral sea beds through afforestation. We collected scientific data and evidential materials, including official publications, unpublished reports, survey responses, and opinions of stakeholders of each project, to select major resilience indicators. Subsequently, the connections between NBS, resilience, and SDGs were analyzed using a qualitative approach. A total of 169 targets included in the 17 SDGs were matched with the resilience factors of each project. Finally, the Korean greening cases (including all reforestation and afforestation activities) were evaluated with the IUCN Global Standard for NBS to determine whether a case is an NBS action, and subsequently, access its performance. The findings of the analyses have implications for future design and access to NBS projects.

\section{Domestic Reforestation Projects of Korea}

\subsection{Korea}

Korea includes 6.3 million ha of mountainous forest areas, covering $63 \%$ of the total national area [20]. However, Korea underwent the Japanese colonial period and the Korean War in the early 1900s, which destroyed forests. During the Japanese colonial period (1910-1945), natural resources were severely exploited with the growing stock of forests declining from 700 million $\mathrm{m}^{3}$ to 200 million $\mathrm{m}^{3}$ [21]. The following Korean War (1950-1953) further caused severe forest cover loss. During the same time, the majority of Korean citizens were experiencing extreme poverty, and fuelwood was used as the primary source of energy for cooking and heating [22]. In addition, slash-and-burn agriculture increased rapidly during this period, covering areas over 1.2 million ha; moreover, the number of slash-and-burn farmers reached almost 2 million, accounting for $7 \%$ of the total population and $12 \%$ of farmers during that period [22]. Consequently, approximately half of the total forest area in the 1950s was converted into bare mountains with few trees; additionally, the mean growing stock per ha was only $5.7 \mathrm{~m}^{3} \mathrm{ha}^{-1}$ in 1953 , which accounted for only $3.5 \%$ of the level in $2019\left(161.5 \mathrm{~m}^{3} \mathrm{ha}^{-1}\right)$ [20].

Since the 1960s, the Korean government has launched various forest protection, reforestation, and erosion control projects through the establishment of the KFS in 1967; consequently, forest rehabilitation, achieved in over 20 years, was guided by the national forestry plan, which was revised every ten years. The shifting aims and activities of the plans were milestones for the forest rehabilitation process in Korea. 
The First 10-Year Forest Rehabilitation Plan (1973-1978) had the following major aims: (1) to promote a national reforestation movement in which all citizens can participate, (2) to expedite forestation by planting fast-growing trees (larch, poplars, black locusts, etc.), (3) to create fuel forests, and (4) to rebuild slash-and-burn fields [23]. This plan was scheduled to be completed in 1982, but was completed four years in advance because of the early reforestation achievement of 1 million hectares (Table 1). This rapid reforestation was possible because of the active participation of citizens guided by robust governmental and administrative powers. For example, the Arbor Period (21 March-20 April) was designated as a national event that involved several million participants from the military, administrative agencies, schools, villages, and private organizations [22]. The Second 10-Year Forest Rehabilitation Plan (1979-1987) emphasized the economic role of forests. Along with fast-growing trees to ensure greening, few economically viable trees were planted to produce timber and fruit. More than 1 million hectares of land was reforested with 325,000 ha of economically viable trees; additionally, most deforested mountainous areas were restored during this period [24]. With the establishment of forests to some extent, the third plan, named the Forest Resource Plan (1988-1997), aimed to develop income streams and improve the public service function of forests to maximize forest utilization [25]. Subsequently, an additional 320,000 ha of economically viable forests were created to supply high-quality and stable timber resources. The distribution system of forest resources was developed for village economies of the mountainous regions, and facilities were established to promote a complete and robust forest culture [25]. With the development of the Fourth Forest Basic Plan (1998-2007), sustainable forest management (SFM) was first introduced as the primary direction for forest management. This indicates a significant conceptual and policy change in Korea that aimed to increase the value of forests by shifting from the "planting policy" to the "tending policy" [26]. The major objective of this plan included the development of forest resource management systems to maintain sustainable forest ecosystems and contribute to the economy.

Table 1. Overview of Korea's reforestation projects [22,27].

\begin{tabular}{cccc}
\hline Forest Plans & Period & Reforestation Area (Ha) & $\begin{array}{c}\text { Number of Trees } \\
\text { Planted (Thousand) }\end{array}$ \\
\hline $\begin{array}{c}\text { First 10-Year Forest } \\
\text { Rehabilitation Plan }\end{array}$ & $1973-1978$ & $1,079,773$ & $2,960,000$ \\
\hline $\begin{array}{c}\text { Second 10-Year Forest } \\
\text { Rehabilitation Plan }\end{array}$ & $1979-1987$ & $1,060,000$ & $1,915,000$ \\
\hline Forest Resource Plan & $1988-1997$ & 323,960 & 837,000 \\
\hline Fourth Forest Basic Plan & $1998-2007$ & 208,997 & 518,000 \\
\hline
\end{tabular}

\subsubsection{Resilience Analysis \\ Environmental Resilience}

An increase in biodiversity enhances food web complexity and stabilizes several ecosystem functions and ecological processes that regulate energy, nutrient, and organic matter fluxes in an environment, including nutrient recycling and biomass production [28]. The Korean reforestation projects secured large areas of vegetation cover and enhanced soil fertility and stability. Increased soil quality facilitated the growth of other plants, which in turn provided food and shelter for animals. The number of species in the Korean Peninsula was first counted as 28,462 in 1996, which gradually increased to 54,428 in 2020 [29]. Particularly, 13,400 animal species (vertebrates and invertebrates) and 900 species of higher plants were recorded. Additionally, the population of animals in mountainous and hilly areas increased following reforestation. During 1969-2000, the average population (numbers per 100 ha) of ring-necked pheasant and water deer increased from 8.6 to 19.4 and 1.2 to 4.1 , respectively (Figure 1) [30,31]. The deer population continually increased to 7.9 until 2019, whereas the pheasant population declined after the late 1990s, possibly 
due to urbanization and habitat loss [31-33]. However, the wild boar population gradually increased from 1.3 in 1978 to 6.8 in 2019 [30-32].

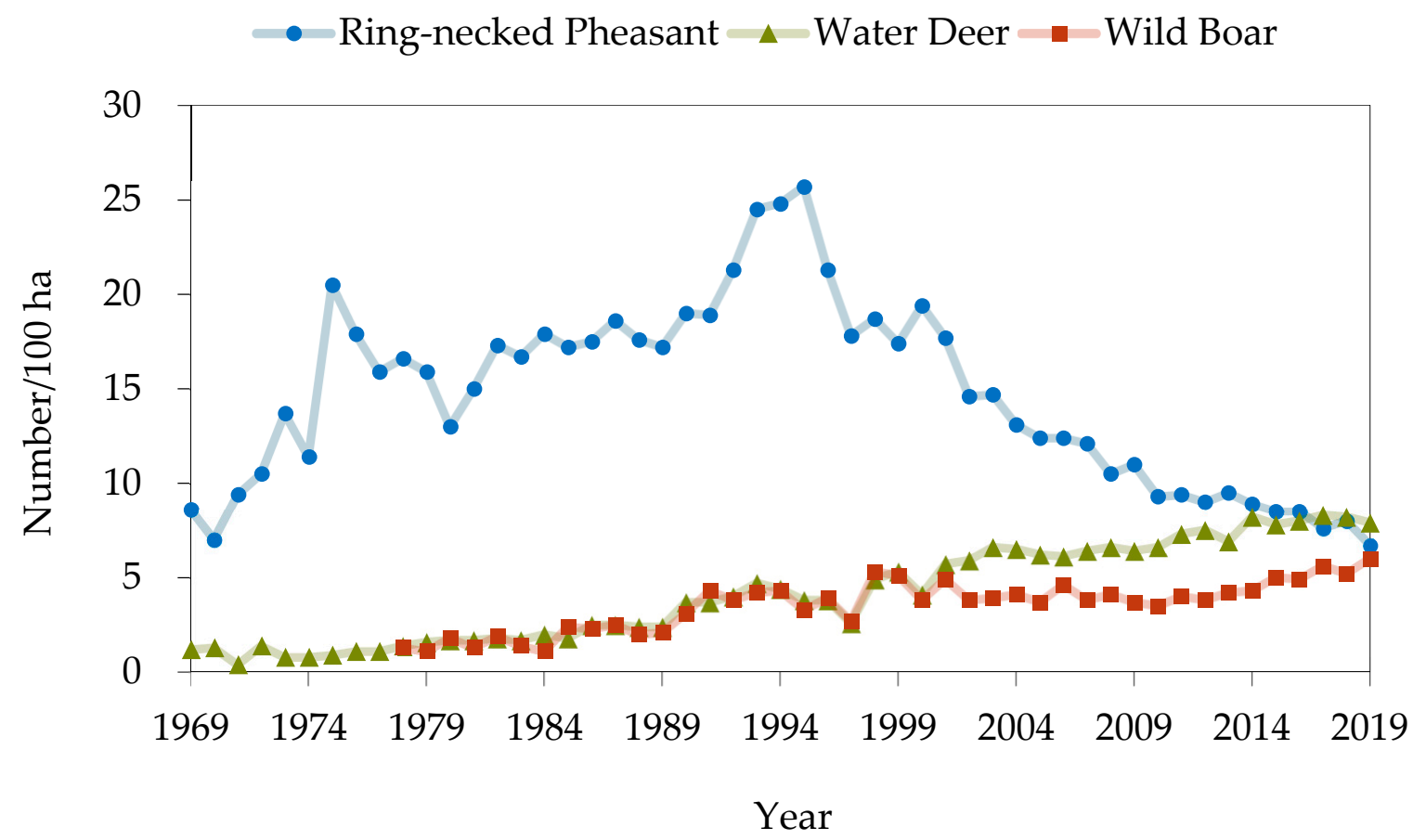

Figure 1. Increase in the animal populations in the mountainous and hilly areas of Korea from 1969 to 2019 [30-32].

Reforestation enhances the water retention capacity and stability of soils, both of which are vital for maintaining forest ecosystems [34]. The water retention capacity can be determined by calculating water yield, an amount of water supply by land cover, and soil stability of forests can be determined by calculating soil erosion mass, an amount of soil loss of and land cover. According to a modeling estimation conducted by Lee et al., during 1971-2010, the annual water yield (million tons) ranged from 341 to 4860 in the presence of forestation, whereas it ranged from 142 to 4683 in the absence of forestation [35]. The net effect of reforestation, which was calculated using the difference between the annual water yield values of these two cases, gradually increased with time. During the same period, the annual soil erosion mass decreased by $83 \%$ from 24 to 4 teragrams (Tg) [35]. In addition, reforestation in Korea improved the soil physicochemical qualities in the reforested areas, with particularly significant improvements in old forest stands [36,37]. Furthermore, after reforestation, the thickness of the litter layer, soil organic matter content, and nutrient content (including phosphorus and calcium) of the soils were found to increase [37].

Reforestation has tremendous potential for mitigating climate change because forests sequester atmospheric carbon dioxide into above and belowground biomass and soils [38]. Long-term reforestation in Korea has rapidly increased carbon sequestration in forests. Lee et al. reported that the carbon stock of Korean forests, including biomass, dead wood, soil organic matter, and litter, increased from $422.4 \mathrm{Tg} \mathrm{C}$ in 1954 (immediately after the Korean War and before the onset of reforestation operations) to $903.5 \mathrm{Tg}$ C in 2012 [39]. Moreover, according to the National Greenhouse Gas Inventory Report of Korea, the atmospheric carbon dioxide sequestered by forests in 2018 was $45.6 \mathrm{Tg} \mathrm{CO}_{2}$ [40].

\section{Socio-Economic Resilience}

Forest resources generate income by providing employment opportunities through the sale of forest products, thus playing an essential role in maintaining the livelihood of rural households and contributing to the national economy. The proportion of the Korean forest resources was estimated annually and converted into monetary values. During 
1974-2019, the annual forest resource production increased from 116 to 6567 billion South Korean Won (KRW; 1150 South Korean Won $\approx 1$ United States Dollar as of 2021) [41]. The resource production included the growing stock of trees in reforested areas, landscape trees, nuts, mushrooms, wild edible herbs, and other products, such as sawdust, medicinal plants, wood sap, firewood, etc. (Figure 2). Particularly, cultivated chestnuts in the nut sector were a significant source of income and food during the 1960s and the 1970s.

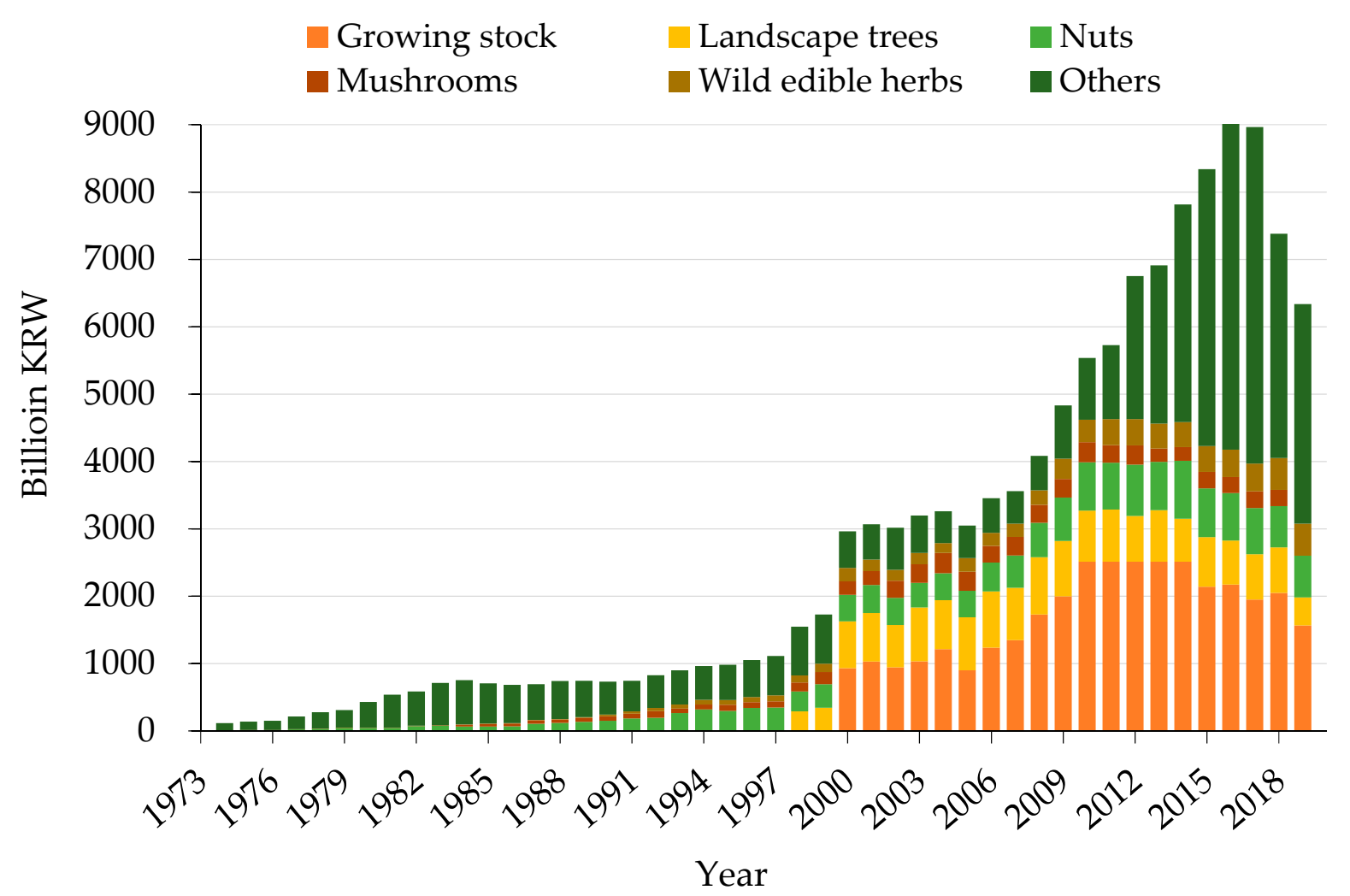

Figure 2. Changes in the forest resource production from 1974 to 2019 in Korea [41].

Forests provide several ecosystem services, especially the provision of clean air and water that ensure human well-being. These forest-derived public services are important indicators of socio-economic resilience. The public value of Korean forests based on their services has been assessed regularly. In the past 30 years (1987-2018), the public service value (trillion KRW) of Korean forests has continuously increased from 17.7 to 221.2 (Figure 3) [42-44]. The ecosystem service of air purification can be divided into three sub-sections: greenhouse gas (GHG) absorption, oxygen production, and air pollutant reduction. The public value of forests increased significantly during evaluations in 2018 because it added the function of carbon storage by forest soil, which was not covered in the previous evaluations, to the GHG absorption service of forests [44]. Furthermore, a positive outlook for securing clean energy is expected in Korea because the production and use of wood-based fuels have increased, with over 330,000 tons of wood pellets manufactured in 2020 [45]. Wood pellets release fewer air pollutants, such as sulfur oxides and nitrogen oxides, than fossil fuels, and have been recognized as clean fuels, which do not emit GHGs, by the United Nations Framework Convention on Climate Change (UNFCCC). 


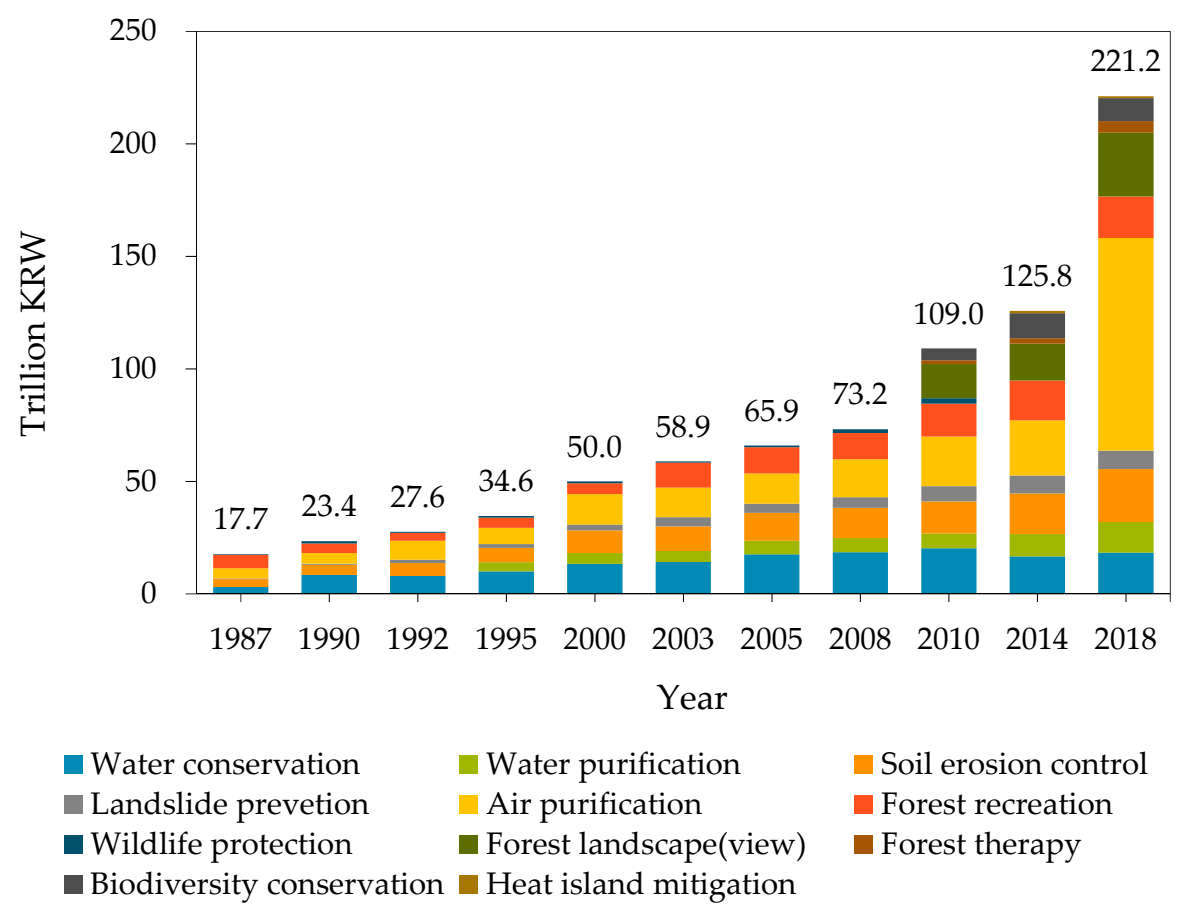

Figure 3. Changes in the public value of the public services of the Korean forests from 1987 to 2018 [42-44].

\section{International Afforestation Projects of Korea}

\subsection{China}

The northern and northwestern regions of China mainly consist of arid and semiarid areas. These areas include the Gobi Desert, Taklamakan Desert, and the Kubuqi Desert. The yellow dust issue is caused by the sand, dust, and pollutants that originate from these deserts because they move along seasonal winds and spread to distant and far-off regions [46-48]. Yellow dust is known for causing problems in human health, agriculture, aviation, and manufacturing industries in China and its neighboring countries [46,47]. Changes in patterns and magnitude of rainfall and increasing temperature caused by climate change have been increasing the desert area. Compared to the late 1900s, drylands are expected to grow by $11 \%$ and $23 \%$ under the future GHG concentration scenarios of the Representative Concentration Pathways (RCP) 4.5 and RCP 8.5, respectively. RCP 4.5 is a "stabilization scenario" in which the policy is implemented and atmospheric GHG concentrations are reduced to the middle of the century, and RCP 8.5 is a scenario of "comparatively high greenhouse gas emissions" caused by rapid population growth, high energy requirements, fossil fuel dominance, and lack of climate change measures. This means that by the end of the century, drylands might account for $50 \%$ to $56 \%$ of the land on Earth under RCP 4.5 and RCP 8.5, respectively. Consequently, the damage caused by the yellow dust is expected to increase further [48].

In response to this issue, Future Forest has been conducting desertification and yellow dust prevention projects in China since 2002 with ODA from the Korean government and with financial support from Korean private companies, such as Korean Air and Bank and Credit Card (BC Card). The duration of the ongoing project is 35 years (2006-2041), and the project site is located in the Kubuqi Desert, which is administratively a part of Dalad Banner, Ordos City, China. As of 2019, under the project, approximately 12 million Populus and Salix trees were planted over a total area of 4741 ha on both sides of the Jiechai Road, which crosses the easternmost part of the Kubuqi Desert in the north-south direction [49]. The planting resulted in the creation of a green wall approximately $16 \mathrm{~km}$ long and $600 \mathrm{~m}$ wide, which is expected to block wind and sand and prevent further expansion of the desert area, thus managing the environmental, social, and economic issues caused by yellow dust. 


\subsubsection{Resilience Analysis}

Environmental Resilience

Vegetation cover at the project site increased significantly. The average enhanced vegetation index (EVI) value of the plantation area increased from 0.07 in 2006 to 0.12 in 2016. In some sites with virtually no previous vegetation $(E V I=0.0)$, the EVI reached approximately $70 \%$ of the EVI of the adjacent natural green areas. The EVI of the desert areas surrounding the plantation was stagnant at 0.06. Notably, since 2013, a band of vegetation across the north-south direction of the Kubuqi Desert has been observed through satellites [49].

Soil surface stability, which resists wind erosion, improved. According to an investigation conducted in 2017, the amount of moving sand at the project site corresponded to only $1 \%$ to $5 \%$ of the desert area [49], partially because of the surface irregularities created by the vegetation cover. In addition, afforestation further reduced sand movements in the surroundings, with a $30 \%$ to $50 \%$ reduction compared with the desert site [49].

Soil physicochemical properties were monitored in 2010. Plantations were found to increase soil carbon and nitrogen concentrations in the overall soil with time. The concentration of plant nutrients, such as $\mathrm{K}^{+}$and $\mathrm{Mg}^{2+}$, also increased. Furthermore, soils showed physical stabilization by decreasing the proportion of sand and increasing the proportion of clay and silt [50].

Furthermore, the biodiversity at the project site increased. Monitoring results of 2015 reported that more than 35 wildlife species, including plants, insects, lizards, birds, and small mammals, returned to the site. Among these, 20 species included naturally regenerated plants that grew along with manually planted trees [49]. This indicated that an ecosystem can be restored through afforestation by providing suitable habitat for various organisms.

Finally, afforestation showed to contribute to global warming mitigation because trees absorb atmospheric carbon dioxide, a major GHG, and convert it into biomass. Trees planted in the early years of the project grew to a height of $10 \mathrm{~m}$ or more [51], and their contribution to GHG reductions could be calculated quantitatively.

\section{Socio-Economic Resilience}

Vegetation cover and soil stabilization caused by afforestation improved the regional air quality by reducing the amount of moving sand and dust [49]. A questionnaire survey study targeting 224 local residents and government officials of Ordos City was conducted in 2015 to ascertain the socio-economic performance of the afforestation project [52]. Respondents rated the statements of the questionnaire on a five-point Likert scale $(1=$ strongly disagree, $2=$ disagree, $3=$ neither agree nor disagree, $4=$ agree, and $5=$ strongly agree). On asking whether the afforestation project had a positive impact on the local environment, respondents gave positive answers ( $4.03 \pm 0.86$, mean \pm standard deviation). The overall impact of the project on the local community and economy was also found to be productive (3.92 \pm 0.87$)$.

Moreover, most respondents benefited from the project, with $54 \%$ of the total respondents agreeing that the project improved the local environment. Additionally, 21\% of the respondents highlighted that they acquired afforestation skills, and $16 \%$ mentioned the availability of employment opportunities. The annual increase in seedling survival rates is an evidence of skill transfer and manpower training. The survival rate of Salix increased from $49 \%$ in 2010 to $91 \%$ in 2015, and that of Populus increased from $61 \%$ in 2010 to $91 \%$ in 2015 [52]. Presently, residents have started trusting the newly acquired skills. According to a survey conducted by the Future Forest, $82 \%$ of the residents responded that local governments and residents can continue to manage the project site even after the termination of foreign assistance [49].

Moreover, afforestation generated alternative sources of economic incentives for rural villagers. The rural community gradually declined as industrialization and desertification caused a large proportion of the rural population residing near the Kubuqi Desert to migrate 
to Ordos City. However, the afforestation project created employment opportunities in rural areas, with people earning higher income in the desert regions than in cities in some cases, which in turn facilitated the return of people to the rural areas. Some people resided in cities for the education of their children while working for afforestation projects in the desert villages [49].

\subsection{Mongolia}

Climate change and other anthropogenic activities have caused unpredictable and harsh winters and droughts in Mongolia [53,54]. Presently, approximately $90 \%$ of the area in Mongolia is threatened by desertification [55]. The livelihood of herders has drastically declined due to extreme weather events that have increased the mortality of their livestock and caused land degradation. Approximately 40\% of Mongolians live in rural areas and rely on livestock farming $[55,56]$. Due to these deteriorating environmental and economic conditions, however, many have been forced into living in urban slums, as they cannot sustain themselves and their families financially [56].

In the early 2000s, GAN and the Korean government collaborated on an afforestation initiative in Mongolia to reduce desertification and yellow dust while fostering regional communities. Under this initiative, a promotional approach, the sustainable regional development model (SRDM), was developed. The SRDM, which addresses region-specific social, economic, and environmental crises in a holistic sense, is considered to be a part of the NBS concept. Particularly, this project emphasizes the recovery and resilience of the local community, with a goal to transfer the afforestation projects to the residents. In 2019, 69,920 trees were planted in nine afforestation sites, with a total of 770,000 trees planted in 680 ha since the beginning of the project in 2000 [57].

\subsubsection{Resilience Analysis}

Environmental Resilience

Afforested trees form green ecosystems. Herbaceous plants were grown in barren fields along with trees. The survival rate of the seedlings was close to $80 \%$, and the average grass production in the project site reached 3.2 tons per ha [58].

Afforestation improved soil fertility at greening sites. GAN reported a significant increase in root nodules, which is a hypertrophic growth of roots formed by the interactions between soil microbes and plants [59]. This indicated an increase in soil microbes and microbial activity. Because soil microbes are closely related to soil organic matter content and soil fertility [60], we can conclude that soil fertility was enhanced by the afforestation project; additionally, the water retention capacity of the soil was enhanced after afforestation. Furthermore, because the roots of vegetation modify soil structures and hold water efficiently, the average water content of the soil increased, while both evaporation and runoff rates decreased [56].

Finally, afforestation contributed to the soil surface stability. Moving dust was reported to reduce at all the project sites. For instance, a project site in Bayannuur generally experienced 50 dust storms on average annually. However, after afforestation, the forest belt functioned as a windbreak; consequently, dust winds were not observed in 1200 ha of areas surrounding the project sites [56].

\section{Socio-Economic Resilience}

Agroforestry, an integrated form of agriculture that combines forests and farmlands, has been suggested as an alternative income source to livestock farmers. This is because the present practice of animal husbandry is the strongest anthropogenic factor that degrades pasturelands in Mongolia [55]. Under the project, farmlands were formed either in vinyl greenhouses or in plantation sites to cultivate vegetables, including potatoes, carrots, and onions. Trees planted on the boundaries of the cultivation sites acted as windbreaks and protected crops from sandstorms and desiccation. In 2018, the project yielded 12 types of 
vegetables weighing approximately $3000 \mathrm{~kg}$, followed by approximately $6300 \mathrm{~kg}$ of harvest the following year $[57,61]$. The harvests were sold in local markets to generate profits.

Under the afforestation project, fruit trees such as sea buckthorn (Hippophae spp.), commonly referred to as vitamin tree, and black currant (Ribes spp.) were planted. Generally, the fruits from these trees are sold for USD 3 and 5 per kg, respectively [58]. The yield of the trees gradually increased every year, with the production of sea buckthorn fruit reaching $3700 \mathrm{~kg}$ in 2019 [57]. Since October 2019, a fruit processing plant that can produce juice, oil, powder, and other products with an added value from fresh harvests of these fruits has been under construction [62].

Locals, low-income individuals, and eco-refugees displaced by shifting weather conditions and desertification were recruited under the projects. Payment for labor, including seedling production and planting, became the primary source of income for these individuals. As of 2019, the projects were established in nine locations, and 180 locals were employed for various project activities [61]. In addition to their daily wages, local people grew seedlings themselves and sold them to GANs for USD 3 per tree [58].

Our analysis of the reports and published data indicated that the afforestation capacity of individuals and communities has improved. An education center was built to provide forestry-related education and training for residents and public officials. The center recently received a license from the Mongolian government as a professional educational institution that can issue a completion certificate. Knowledge and skills on afforestation-related topics such as orcharding, agriculture, planting, and overall project operations are shared with local trainees in these centers. To date, more than 2800 residents have been trained [56]. Additionally, education also increases the awareness of the citizens towards global climate crisis. Accordingly, various events, including environmental summer schools and environment bazaars, were held to promote awareness and encourage locals to participate in activities related to forest conservation [63].

\subsection{Kazakhstan}

The Aral Sea is located in the Central Asia region and stretches across the borders of southern Kazakhstan and northern Uzbekistan. It was once the world's fourth-largest inland lake, with maximum depth reaching $67 \mathrm{~m}$ and covering an area of approximately $68,000 \mathrm{~km}^{2}$ until the 1960s [64]. However, the Aral Sea level dropped starting from the 1960s, divided into two parts since the 1980s, and according to the observations in 2020, only $15 \%$ of the Aral Sea area remains $[64,65]$. The rapid desiccation of the Aral Sea was due to large-scale cultivation in the 1960s that accelerated the withdrawal of irrigation water from the primary water sources of the Aral Sea. Consequently, the salt concentration of the lake increased by more than ten times, and the diversity and populations of species in the Aral Sea declined sharply [66]. Subsequently, fishery was officially stopped in the 1980s. The exposed substrate of the Aral Sea that had high salt concentration was unsuitable for vegetation growth. Additionally, the soil was not held together strongly due to the lack of plant roots; consequently, unstable sand and dust scattered to nearby ecosystems and exerted salt stress [67].

The afforestation project aided by the Korean government began with soil preparation work in spring 2018, followed by three sequential saxaul afforestation activities in autumn 2018, spring 2019, and autumn 2019. Saxaul (Haloxylon aphyllum) was selected as the planting species because it is indigenous to the dry Central Asia climate and is resistant to salt stress [68,69]. A total of 3,759,400 saxaul trees were planted in 10,800 ha on the eastern Aral seabed in the Kyzylorda region [66].

\subsubsection{Resilience Analysis}

Environmental Resilience

Changes in soil characteristics following afforestation were examined as part of the ODA. An et al. compared the soil characteristics of four adjacent sites within the northern Aral seabed [70]. The four sites included an exposed area devoid of plants, two plantation 
areas (afforested in 2002 and 2013), and a naturally vegetated area. The 2002 plantation area and naturally vegetated area differed significantly compared with the other sites and showed higher water content and total nitrogen, organic carbon, $\mathrm{K}^{+}$, and $\mathrm{Mg}^{2+}$ concentrations. However, the water content, total nitrogen, organic carbon concentrations, etc., did not show any statistical difference between the two sites, indicating the similar soil amelioration effect between afforested and naturally vegetated areas [70].

According to Khamzina et al., plant species were evaluated in the northern dried Aral seabed from the sites afforested during 1991-2017 [71]. Black saxaul (Haloxylon aphyllum), sarsazan (Halocnemum strobilaceum), lebeda (Atriplex fominii Iljin.), and common wormwood (Artemisia diffusa H. Krasch) were found in the afforestation sites [71]. Stand density and species richness were the highest in the 1991 plantation site among all the evaluated sites. Tree species that were not planted during the afforestation program were assumed to have originated from naturally introduced seeds before and after afforestation [71]. Thus, afforestation promoted diverse vegetation. Additionally, as grasslands and forests serve as suitable habitats for various species of animals, the enhancement of terrestrial biodiversity can be expected.

Chang et al. investigated the biomass accumulation and carbon stocks of afforested vegetation in the northern Aral seabed [72]. The carbon stock of saxaul trees was $9.70 \mathrm{C} \mathrm{g} \mathrm{m}^{-2}$ in the total biomass [72], indicating that carbon sequestration through afforestation reduces carbon dioxide, a major GHG that initiates climate change.

Socio-Economic Resilience

Vegetation acts as a windbreak, and plant roots stabilize the soil surface by physically trapping the substrates. Furthermore, the soil is stabilized by an increase in soil organic matter that contributes to soil aggregate formation, a relatively steady soil bundle structure [73-75]. Afforestation can also decrease a considerable amount of windblown dust [76]. Consequently, similar to the case in China, afforestation reduced diseases related to poor air quality among residents [49].

Saxaul is also suitable for firewood and can be processed into other useful products. Forest products generated through afforestation can support residents by providing necessary resources and livelihood opportunities. Moreover, promoting cotton and agricultural productivity secured by improving soil characteristics can benefit residents with resource provision [66].

Afforestation occurs in several stages: seed collection and processing, seeding, seedling cultivation and excavation, and planting in the selected areas. Residents living in the surrounding areas provide the necessary labor force. Fishers and farmers who have lost their livelihood can participate in the afforestation projects. As the required financial assistance to run the programs is provided by the aid from ODA donor countries, local communities can generate income through the afforestation project.

In addition, afforestation can support herding. Trees control the microclimate and improve soil properties suitable for the rapid introduction of plant species [69,77], thus supporting floral and faunal diversity. Because herbaceous plants are a food source for livestock, afforestation can assist in sustaining livestock, thereby providing alternate means of livelihood for the residents.

In 2019, the KFS invited ten forest officials from Kazakhstan to visit Korea and share Korea's greening experience, explore related organizations, and discuss future afforestation projects. Nurturing experts, who can work locally, are essential to ensure the continuity of the project; therefore, extending the project in terms of training and education is desirable [66].

\section{Steps from NBS Actions for Resilience Building and Assessment of SDGs}

As shown in Table 2, each Korean reforestation and afforestation project underwent a resilience assessment of the environmental and socio-economic aspects to demonstrate its impacts on enhancing ecological and social sustainability, which differ depending on 
the aims and scope of the projects. The resilience indicators were then matched to the corresponding SDGs.

Table 2. Summary of resilience and SDG achievements through the NBS-related projects.

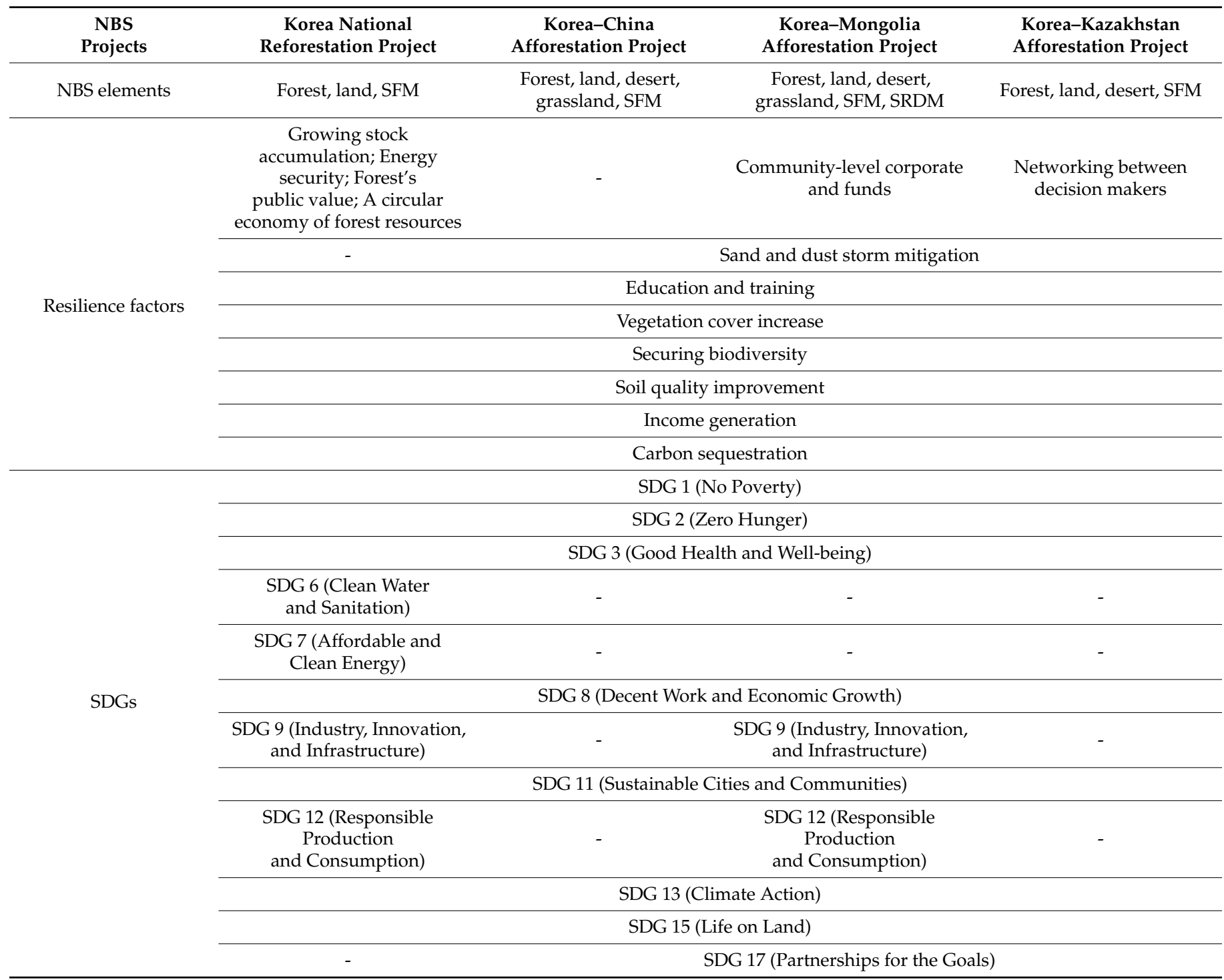

SFM: sustainable forest management, SRDM: sustainable regional development model.

Figure 4 illustrates the NBS elements, resilience indicators, and SDGs shared by the four projects. Creating forests was the major NBS activity that was common among the projects. Newly established vegetation improved soil quality and stability and increased local biodiversity. These changes promote the resilience of the ecosystem by enhancing plant productivity and developing complex relationships among biotic and abiotic factors, thus reducing the risks caused by natural disasters and anthropogenic activities $[28,78,79]$. Ecosystem sustainability achieved through afforestation is associated with SDG 15, which addresses the conservation of terrestrial ecosystems and biodiversity. In addition, carbon sequestration by the newly established vegetation assisted each project in achieving SDG 13 on climate action through GHG reduction.

All cases indicated socio-economic sustainability by promoting income increase and job opportunities. Residents were employed to provide labor for seed collection and processing, seeding, seedling cultivation and excavation, planting, or agroforestry. The sustainability of local society is associated with SDGs 1,2, and 8, which are aimed to overcome poverty and hunger and achieve economic growth. A decrease in dust storms, which has 
been observed in ODA projects, benefits both the ecosystem and society because it reduces soil loss and improves air quality, in turn contributing to SDGs 15, 3, and 11, which address ecosystem, human health and well-being, and sustainable communities, respectively.

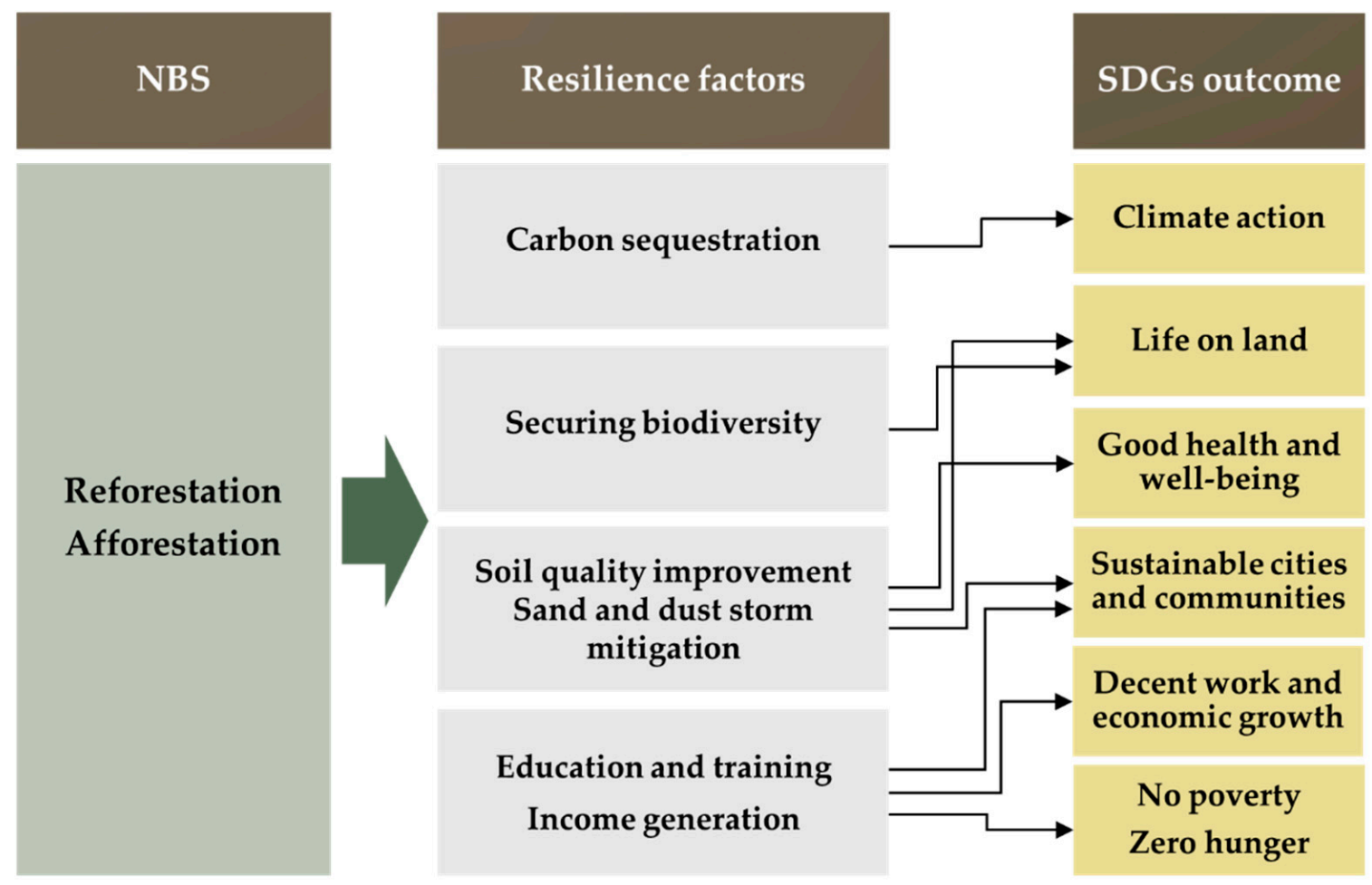

Figure 4. Common elements of the NBS, resilience factors, and SDG outcomes from the reforestation and afforestation projects conducted by Korea.

The differences between the projects are also evident. Compared with the other afforestation cases, the Korean reforestation project is the largest national project that has been conducted for the longest duration. In this project, economic benefits were derived by including diverse plant species, such as fruit trees, rapidly growing trees, and fuelwood trees. The project achieved SDG 9 and SDG 12 because it established industrial systems and infrastructures that connected the production, distribution, and consumption chains of various forest resources. Fuelwood generation further contributed to accomplishing SDG 7 and SDG 12 by reducing the dependence on fossil-derived energies. The increased water yield in the forest soils pertains to SDG 6. This differed from Mongolia's afforestation projects because the latter empowered residents through regular training and promoted economic self-reliance of the local community by establishing afforestation-related corporates and funds. With the added capacity, community members would be able to respond to various potential crises in the future and significantly contribute to the development of society $[12,13]$. Such reinforcement of the local community emphasizes SDGs 1, 2, 8, and 11. Additionally, the construction of the fruit processing factory, which is an infrastructure for industrial development, can contribute to achieving SDGs 9 and 12. A distinct aspect of Kazakhstan's afforestation project is the improvement of soil quality. Afforestation and related academic research conducted in highly saline soils have yielded valuable results regarding the need for planting to urgently overcome the saline stresses [70-72]. Furthermore, networking between various stakeholders and decision makers in Kazakhstan and Korea can promote long-term community sustainability, which corresponds to SDG 17.

\section{Evaluation of Korea's Greening Projects Using the Global Standard for NBS}

Because a sustainable system can be built through NBS activities, incorporating the concept of NBS into existing and future development and restoration projects is recom- 
mended. However, designing a project using the concept of NBS will be a serious concern for decision makers, because of its comprehensive characteristics. Overall, future implementers of NBS can consider a standardized approach and a credible self-assessment method, such as the IUCN global standard for nature-based solutions (Table 3). The standard was launched in July 2020 and consists of eight criteria and 28 indicators [80].

Table 3. Criteria and brief guidelines of the IUCN Global Standard for NBS. Modified from IUCN [80].

\begin{tabular}{|c|c|}
\hline Criteria & Summary of the Guidelines \\
\hline Criterion 1: NBS effectively addresses social challenges. & $\begin{array}{l}\text { NBS is designed as a response to the societal challenge identified as } \\
\text { a priority. }\end{array}$ \\
\hline Criterion 2: The design of NBS is informed by scale. & $\begin{array}{l}\text { NBS is designed to respond to the scale of the issue. Scale refers to } \\
\text { geographic, economic, ecological, and societal } \\
\text { aspects of the landscape. }\end{array}$ \\
\hline $\begin{array}{l}\text { Criterion 3: NBS results in a net gain to biodiversity and } \\
\text { ecosystem integrity. }\end{array}$ & NBS is designed to enhance the sustainability of the ecosystem. \\
\hline Criterion 4: NBS is economically viable. & $\begin{array}{l}\text { NBS considers the return on investment, efficiency of the NBS } \\
\text { intervention, and equity in the distribution of benefits and costs. }\end{array}$ \\
\hline $\begin{array}{l}\text { Criterion 5: NBS is based on inclusive, transparent, and empowering } \\
\text { governance processes. }\end{array}$ & $\begin{array}{c}\text { NBS is socially equitable; they acknowledge and involve } \\
\text { various stakeholders. }\end{array}$ \\
\hline $\begin{array}{l}\text { Criterion 6: NBS equitably balances trade-offs between the achievement } \\
\text { of their primary goal(s) and the } \\
\text { continued provision of multiple benefits. }\end{array}$ & $\begin{array}{l}\text { NBS balances choices that need to be made to achieve short and } \\
\text { long-term gains and ensures transparent, equitable, and inclusive } \\
\text { processes to determine such trade. }\end{array}$ \\
\hline Criterion 7: NBS has managed adaptively, based on evidence. & $\begin{array}{c}\text { NBS adapts and evolves according to continuous learning about } \\
\text { system-wide processes to minimize risks and } \\
\text { effectively harness ecosystem resilience. }\end{array}$ \\
\hline $\begin{array}{l}\text { Criterion 8: NBS is sustainable and mainstreamed within an appropriate } \\
\text { jurisdictional context. }\end{array}$ & $\begin{array}{l}\text { NBS embed the concept and actions into policy or } \\
\text { regulatory frameworks as well as linking to national targets or } \\
\text { international commitments. }\end{array}$ \\
\hline
\end{tabular}

The Korean greening projects (including domestic reforestation and overseas afforestation projects) were evaluated according to the IUCN global standard criteria on a trial basis, starting with the assessment of whether an NBS project was selected to address societal challenges. Korea's greening projects achieved Criterion 1 because they aimed to reduce yellow dust, relieve environmental refugees, and generate local income [22,49,56,66]. Activities were conducted at an appropriate scale nationally or regionally (Criterion 2) and improved ecosystem conditions and biodiversity through planting (Criterion 3) $[22,49,56,66]$. The attempts to build an economic foundation through agroforestry, planting fruit trees, and encouraging active decision making by community members are particularly prominent in ODA projects (Criteria 4 and 5) $[49,56]$. Criterion 6 focuses on maximizing the provision of multiple benefits from NBS actions and reasonably managing trade-off effects. The enhanced environmental and socio-economic resilience result from the Korean projects can be understood as benefits from various aspects of the NBS (Criterion 6), which is also shown in other NBS cases $[81,82]$. Project management from several years to several decades has been updated regularly through timely monitoring and evaluation (Criterion 7). Finally, Criterion 8 evaluates the possibility of introducing NBS actions into policies and contributing to the global 2030 agenda. Korea's afforestation projects partially adhere to Criterion 8 because they contribute to various sections of the SDGs. The achievement of the resilience indicators under each criterion should be analyzed more closely to examine whether there was rigid conformity between the projects and the standards. Nevertheless, the overall context of the Korean projects appears to be consistent with the NBS actions as defined by the standard global framework.

\section{Conclusions}

This study reviewed four either completed or ongoing NBS-related projects: one reforestation project conducted in the Republic of Korea and three afforestation projects 
conducted in arid regions of Asia. These projects aimed to tackle global environmental issues, especially land degradation and desertification. Although all projects practice NBS by managing ecosystems to mitigate environmental and socio-economic crises, each project has a distinct focus. The Korean reforestation projects aimed to restore the devastated national territory and revitalize the economy. China's afforestation project aimed to build a green wall across the desert to mitigate the yellow dust affecting the environmental and social conditions in Northeast Asia. Furthermore, Mongolia's afforestation projects aimed to prevent desertification and secure community stability, while Kazakhstan's afforestation project aimed to desalt and ameliorate the exposed substrate of the dried Aral Sea.

The following conclusions are drawn by comparing the differences and similarities of these projects. First, NBS activities carefully designed to include various natural and social elements can promote the resilience of ecosystems and social systems, which in turn can be linked to multiple SDGs. The Korean reforestation project was associated with 11 SDGs, while eight SDGs were addressed through afforestation projects in China, Mongolia, and Kazakhstan. SDGs can be achieved in a broader sense with more data that can support other domains of SDGs, such as social inequalities (SDG 10). Therefore, designing a comprehensive NBS project that influences various environmental, social, and economic fields can incorporate a broader spectrum of SDGs.

Second, to fulfill the first implication, analyzing the natural and socio-economic systems of the project sites and identifying the resilience indicators that determine which factors affect their sustainability are desirable while designing an NBS project. In addition, based on the specific purpose of the project and the conditions of the target areas, regionspecific strategies under the concept of NBS should be established and applied. For example, Mongolia applied a specific methodology by creating the SRDM.

Third, future implementers of NBS can consider a standardized approach and a credible self-assessment method, such as the IUCN Global Standard for NBS-related projects. Moreover, for the efficient application and expansion of the NBS concept, incorporating NBS into other sustainable development agendas and policy fields is important. For example, carbon dioxide reduction accomplished by vegetation establishment as an NBS activity can be effectively incorporated into the nationally determined contribution, a plan that submits a report to the UNFCCC on the proportion of GHGs that a country which has signed the Paris Agreement will voluntarily reduce, considering its responsibility and capacity for carbon dioxide emissions.

Finally, because NBS projects vary in scale, period, and location, their outcomes may also vary. Therefore, if common standards for evaluating the performance and common system for licenses issued for NBS projects are established, this will promote the revitalization of the NBS initiatives. In addition, to access the results of the NBS projects related to resilience building, scientific measurements must be incorporated into the evaluations. For instance, survey statistics answered by the residents are important indicators for education and awareness sharing toward the NBS projects, while experimental analysis for soil conditions and investigations for biodiversity are indicators for the sustainability of the ecosystem. As shown in some cases introduced in this study, there may be more positive impacts on resilience building. However, evaluations are fragmented and limited to qualitative assessments because sufficient data were unavailable for quantitative analysis. Since qualitative and verbal data are not sufficiently reliable to be used for the evaluations, acquiring scientific and quantitative evidence to examine the process of the project and draw clear results is important.

The overall implications of Korea's NBS experiences repeatedly emphasize the importance of harmonizing nature conservation and human progress. Experts and policymakers should continue to explore ways to implement NBS more efficiently. Korea's experiences and contributions to NBS actions are expected to provide other countries with reference guidelines by minimizing trial and error in the NBS implementation process, thereby fulfilling its potential to address social and environmental challenges. 
Author Contributions: Conceptualization, Y.S. and G.K.; methodology, Y.S.; formal analysis, G.K., J.K., Y.K. and O.T.G.E.; writing—original draft preparation, G.K., J.K., Y.K. and O.T.G.E.; writingreview and editing, Y.S., W.L., S.C. and J.A.; visualization, G.K.; supervision, Y.S., W.L. and S.C. All authors have read and agreed to the published version of the manuscript.

Funding: This study is supported by the Korea Forest Service and carried out with the "Project on Reforestation and Income Generation for Local People in Tajikistan". This work is also supported by the Korea Agency for Infrastructure Technology Advancement (KAIA) grant funded by the Ministry of Land, Infrastructure and Transport (grant number 21UMRG-B158194-02).

Institutional Review Board Statement: Not applicable.

Informed Consent Statement: Not applicable.

Data Availability Statement: Not applicable.

Acknowledgments: Support by the Future Forest and the Green Asia Network is gratefully acknowledged, for providing the evidentiary materials including records and photographs from the field that have assisted the completion of this paper.

Conflicts of Interest: The authors declare no conflict of interest.

\section{References}

1. Cohen-Shacham, E.; Walters, G.; Janzen, C.; Maginnis, S. (Eds.) Nature-Based Solutions to Address Global Societal Challenges; IUCN: Gland, Switzerland, 2016.

2. Lafortezza, R.; Chen, J.; Van Den Bosch, C.K.; Randrup, T.B. Nature-based solutions for resilient landscapes and cities. Environ. Res. 2018, 165, 431-441. [CrossRef]

3. Raymond, C.M.; Berry, P.; Breil, M.; Nita, M.R.; Kabisch, N.; de Bel, M.; Enzi, V.; Frantzeskaki, N.; Geneletti, D.; Cardinaletti, M.; et al. An Impact Evaluation Framework to Support Planning and Evaluation of Nature-Based Solutions Projects. Report Prepared by the EKLIPSE: Expert Working Group on Nature-Based Solutions to Promote Climate Resilience in Urban Areas; Centre for Ecology and Hydrology: Wallingford, UK, 2017.

4. Bhamra, R.; Dani, S.; Burnard, K. Resilience: The concept, a literature review and future directions. Int. J. Prod. Res. 2011, 49, 5375-5393. [CrossRef]

5. Gunderson, L.; Holling, C.S. Panarchy: Understanding Transformations in Human and Natural Systems; Island Press: Washington, DC, USA, 2002.

6. Pimm, S.L. The complexity and stability of ecosystems. Nature 1984, 307, 321-326. [CrossRef]

7. Bahadur, A.V.; Ibrahim, M.; Tanner, T. The Resilience Renaissance? Unpacking of Resilience for Tackling Climate Change and Disasters. CSR Discussion Paper No.1, Strengthening Climate Resilience Programme; Institute of Development Studies: Brighton, UK, 2010.

8. Curtin, C.G.; Parker, J.P. Foundations of resilience thinking. Conserv. Biol. 2014, 28, 912-923. [CrossRef] [PubMed]

9. Martin-Breen, P.; Anderies, J.M. Resilience: A Literature Review; Institute of Development Studies: Brighton, UK, 2011. Available online: https:/ / opendocs.ids.ac.uk/opendocs/handle/20.500.12413/3692 (accessed on 7 July 2021).

10. Holling, C.S. Engineering Resilience versus Ecological Resilience. In Engineering within Ecological Constraints; Schulze, P., Ed.; National Academies Press: Washington, DC, USA, 1996; pp. 31-44.

11. Adger, W.N. Social and ecological resilience: Are they related? Prog. Hum. Geogr. 2000, 24, 347-364. [CrossRef]

12. Sherrieb, K.; Norris, F.H.; Galea, S. Measuring capacities for community resilience. Soc. Indic. Res. 2010, 99, 227-247. [CrossRef]

13. Koliou, M.; van de Lindt, J.W.; McAllister, T.P.; Ellingwood, B.R.; Dillard, M.; Cutler, H. State of the research in community resilience: Progress and challenges. Sustain. Resilient Infrastruct. 2020, 5, 131-151. [CrossRef]

14. Martín, E.G.; Giordano, R.; Pagano, A.; Van der Keur, P.; Costa, M.M. Using a system thinking approach to assess the contribution of nature-based solutions to sustainable development goals. Sci. Total Environ. 2020, 738, 139693. [CrossRef]

15. Folke, C.; Carpenter, S.; Elmqvist, T.; Gunderson, L.; Holling, C.S.; Walker, B. Resilience and sustainable development: Building adaptive capacity in a world of transformations. AMBIO 2002, 31, 437-440. [CrossRef] [PubMed]

16. Handmer, J.W.; Dovers, S.R. A typology of resilience: Rethinking institutions for sustainable development. Ind. Environ. Crisis Q. 1996, 9, 482-511. [CrossRef]

17. Acharya, P.; Gupta, A.K.; Dhyani, S.; Karki, M. New Pathways for NbS to Realise and Achieve SDGs and Post 2015 Targets: Transformative Approaches in Resilience Building. In Nature-Based Solutions for Resilient Ecosystems and Societies; Dhyani, S., Gupta, A., Karki, M., Eds.; Springer: Singapore, 2020.

18. Food and Agriculture Organization (FAO). Village Forestry Development in the Republic of Korea: A Case Study. Forestry for Local Community Development Programme (GCP/INT/347/SWE); Food and Agriculture Organization: Rome, Italy, 1982.

19. Food and Agriculture Organization (FAO). Forest Futures: Sustainable Pathways for Forests, Landscapes and People in the Asia-Pacific Region. Asia-Pacific Forest Sector Outlook Study III; Food and Agriculture Organization: Bangkok, Thailand, 2019. Available online: http: / / teaknet.org/fao-2019-forest-futures-\%E2\%80\%93-sustainable-pathways-forests-landscapes-and-people-asiapacific-region (accessed on 7 July 2021). 
20. Korea Forest Service (KFS). Statistical Yearbook of Forestry, 50th ed.; Korea Forest Service: Daejeon, Korea, 2020. (In Korean)

21. Korea Forest Service (KFS). Forestry History. Available online: https://english.forest.go.kr/kfsweb/kfi/kfs/cms/cmsView.do? cmsId=FC_001677\&mn=UENG_01_02_01 (accessed on 23 August 2021).

22. Korea Forest Service (KFS). 50-Year History of the Korea Forest Service (1967-2017); Korea Forest Service: Daejeon, Korea, 2017. (In Korean)

23. Korea Forest Service (KFS). The Second National Forest Resource Plan; Korea Forest Service: Daejeon, Korea, 1979. (In Korean)

24. Korea Forest Service (KFS). The Third National Forest Resource Plan; Korea Forest Service: Daejeon, Korea, 1987. (In Korean)

25. Korea Forest Service (KFS). The Fourth National Forest Basic Plan; Korea Forest Service: Daejeon, Korea, 1997. (In Korean)

26. Korea Forest Service (KFS). The Fifth Forest Basic Plan; Korea Forest Service: Daejeon, Korea, 2007. (In Korean)

27. National Archives of Korea. Available online: https://theme.archives.go.kr/next/forest/outline/businessCondition.do (accessed on 30 October 2021).

28. Cardinale, B.J.; Duffy, J.E.; Gonzalez, A.; Hooper, D.U.; Perrings, C.; Venail, P.; Naeem, S. Biodiversity loss and its impact on humanity. Nature 2012, 486, 59-67. [CrossRef] [PubMed]

29. Ministry of Environment: Environmental Statistics Portal. Available online: http://stat.me.go.kr/nesis/mesp/stat/branch/ branchStat.do?task=I\&menu_id=106H_01_007 (accessed on 23 August 2021).

30. Korea Forest Service (KFS). Creation of Forest Resources. In Forest and Forestry Technique; Korea Forest Service: Daejeon, Korea, 2000. (In Korean)

31. National Institute of Biological Resources. Survey and Resource Management of Wildlife; National Institute of Biological Resources: Incheon, Korea, 2009. (In Korean)

32. National Institute of Biological Resources. 2020 Wildlife Survey; National Institute of Biological Resources: Incheon, Korea, 2020. (In Korean)

33. United Nations Development Programme (UNDP). Sharing Korea's Experience in Sustainable Forestry: Its Possible Applications in Developing Countries; Sustainable Development Goals Policy Brief Series No.10; United Nations Development Programme: Seoul, Korea, 2018.

34. Zuazo, V.H.D.; Pleguezuelo, C.R.R. Soil-Erosion and Runoff Prevention by Plant Covers: A review. In Sustainable Agriculture; Lichtfouse, E., Navarrete, M., Debaeke, P., Souchère, V., Alberola, C., Eds.; Springer: Dordrecht, The Netherlands, 2008.

35. Lee, J.; Lim, C.H.; Kim, G.S.; Markandya, A.; Chowdhury, S.; Kim, S.J.; Son, Y. Economic viability of the national-scale forestation program: The case of success in the Republic of Korea. Eco. Ser. 2018, 29, 40-46. [CrossRef]

36. Lee, C.; Kim, T. Changes in soil characteristics by tree growth in Korean forests. Res. Rep. For. Res. Inst. 1994, 49, 73-80.

37. Lee, H.; An, J.H.; Shin, H.C.; Lee, C.S. Assessment of restoration effects and invasive potential based on vegetation dynamics of pitch pine (Pinus rigida Mill.) plantation in Korea. Forests 2020, 11, 568. [CrossRef]

38. Silver, W.L.; Ostertag, R.; Lugo, A.E. The potential for carbon sequestration through reforestation of abandoned tropical agricultural and pasture lands. Restor. Ecol. 2000, 8, 394-407. [CrossRef]

39. Lee, J.; Yoon, T.K.; Han, S.; Kim, S.; Yi, M.J.; Park, G.S.; Son, Y. Estimating the carbon dynamics of South Korean forests from 1954 to 2012. Biogeosciences 2014, 11, 4637-4650. [CrossRef]

40. Ministry of Environment. National Greenhouse Gas Inventory Report of Korea (1990-2017); Ministry of Environment: Sejong, Korea, 2020. (In Korean)

41. Korea Forest Service (KFS). Forest Resources Production Survey. Available online: https://www.forest.go.kr/kfsweb/ $\mathrm{cop} / \mathrm{bbs} /$ selectBoardList.do?mn=NKFS_04_05_10\&pageIndex=2\&pageUnit=10\&searchtitle=title\&searchcont=\&searchkey= \&searchwriter=\&searchdept=\&searchWrd=\&ctgryLrcls=CTGRY071\&ctgryMdcls=\&ctgrySmcls=\&ntcStartDt=\&ntcEndDt= \&orgId=\&component=\&bbsId=BBSMSTR_1016 (accessed on 23 August 2021). (In Korean)

42. Korea Forest Service (KFS). Evaluation of the Public Function of Forests as of 2010. Available online: https: / /www.forest.go. $\mathrm{kr} / \mathrm{kfsweb} / \mathrm{cop} / \mathrm{bbs} /$ selectBoardArticle.do? nttId=2881339\&bbsId=BBSMSTR_1023\&pageIndex=1\&pageUnit=10\&searchtitle= title\&searchcont=\&searchkey=\&searchwriter=\&searchdept=\&searchWrd=\&ctgryLrcls=\&ctgryMdcls=\&ctgrySmcls=\&ntcStartDt= \&ntcEndDt=\&orgId=\&mn=NKFS_04_06 (accessed on 23 August 2021).

43. National Institute of Forest Science. Report on Evaluation Results of Forest Public Benefit Function as of 2014; National Institute of Forest Science: Seoul, Korea, 2016. (In Korean)

44. National Institute of Forest Science. Results and Implications of Forest Function Evaluation as of 2018; National Institute of Forest Science: Seoul, Korea, 2020. (In Korean)

45. Korea Forest Service (KFS). Wood Pellet Production and Sales. Available online: https://www.forest.go.kr/kfsweb/kfi/kfs/cms/ cmsView.do?mn=NKFS_02_01_11_04_02\&cmsId=FC_000811 (accessed on 23 August 2021). (In Korean)

46. Ai, N.; Polenske, K.R. Socio-economic impact analysis of yellow-dust storms: An approach and case study for Beijing. Econ. Syst. Res. 2008, 20, 187-203. [CrossRef]

47. Kar, A.; Takeuchi, K. Yellow dust: An overview of research and felt needs. J. Arid Environ. 2004, 59, 167-187. [CrossRef]

48. Mirsaeidi, M.; Motahari, H.; Taghizadeh Khamesi, M.; Sharifi, A.; Campos, M.; Schraufnagel, D.E. Climate change and respiratory infections. Ann. Am. Thorac. Soc. 2016, 13, 1223-1230. [CrossRef]

49. Future Forest (Seoul, South Korea). Unpublished Data. 2020. (In Korean)

50. Institute of Yellow Dust and Combating Desertification. Assessment of Plantations for Combating Desertification and Preventing Yellow Dust and Sandstorms in Northeast Asia Subregion; Asia RCU, UNCCD: Bangkok, Thailand, 2010; pp. 163-176. 
51. Korea Forest Service (KFS). The KFS Conducting Blue Sky Project through Planting in the Kubuqi Desert, China. 2018. Available online: https: / / www.forest.go.kr/ (accessed on 7 July 2021). (In Korean)

52. Ji, S.Y.; Lee, S.H.; Lee, O.K.; Choi, J.Y. A survey on the perception of China private antidesertification afforestation support project and evaluation. Korean J. Agric. Sci. 2016, 43, 288-297. (In Korean) [CrossRef]

53. Batjargal, Z. Lessons Learnt from Consecutive Dzud Disaster of 1999-2000 in Mongolia in Asia. In Proceedings of the Open Symposium on Change and Sustainability of Pastoral Land Use Systems in Temperate and Central Asia, Ulaanbaatar, Mongolia, 28 June-1 July 2001.

54. Fernández-Gimenez, M.E.; Batjav, B.; Baival, B. Lessons from the Dzud: Adaptation and Resilience in Mongolian Pastoral Social-ecological Systems; World Bank: Washington, DC, USA, 2012.

55. Dorj, O.; Enkhbold, M.; Lkhamyanjin, S.; Mijiddorj, K.; Nosmoo, A.; Puntsagnamil, M.; Sainjargal, U. Mongolia: Country Features, the Main Causes of Desertification and Remediation Efforts. In Combating Desertification in Asia, Africa and the Middle East; Heshmati, G., Squires, V., Eds.; Springer: Dordrecht, The Netherlands, 2013.

56. Green Asia Network (GAN). 5-Year Strategy Report (2019-2024); Unpublished Data; Green Asia Network: Seoul, Korea, 2020.

57. Green Asia Network (GAN). Green Asia Network Annual Report; Green Asia Network: Seoul, Korea, 2020. (In Korean)

58. Oke, R.; Kim, K.H.; Oh, K.C. Cultivating a Common Future: Five-Year Strategy Report of Green Asia Network. 2014. Available online: https: / / www.ctc-n.org/resources / cultivating-common-future (accessed on 7 July 2021).

59. UNCCD Secretariat. Land for Life: Create Wealth, Transform Lives. 2016. Available online: http:/ /www2.unccd.int/publications/ land-life-create-wealth-transform-livesUNCCD (accessed on 6 July 2021).

60. Hayat, R.; Ali, S.; Amara, U.; Khalid, R.; Ahmed, I. Soil beneficial bacteria and their role in plant growth promotion: A review. Ann. Microbiol. 2010, 60, 579-598. [CrossRef]

61. Green Asia Network (GAN). Green Asia Network Annual Report; Green Asia Network: Seoul, Korea, 2019. (In Korean)

62. Han, S.J. The First Step to Establish the Sea Buckthorn Value Chain (SVC): The Meaning of Fruit Tree Processing Plant. 31 October 2019. Available online: http:/ / www.greenasia.kr/2019/10/31/vol-107-main-story (accessed on 6 July 2021). (In Korean).

63. Lee, S.-J.; Yun, S.-J. Outcomes and challenges of activities of a Korean INGO, the Green Asia Network, to combat desertification and climate change: From a perspective of sustainable development. Civ. Soci. NGO 2013, 11, 67-97. (In Korean)

64. Takano, Y.; Hirosawa, Y.; Mori, S. Environmental management plan for rehabilitation of the Aral Basin. J. Agric. Meteorol. 1993, 48, 537-541. [CrossRef]

65. Li, Q.; Li, X.; Ran, Y.; Feng, M.; Nian, Y.; Tan, M.; Chen, X. Investigate the relationships between the Aral Sea shrinkage and the expansion of cropland and reservoir in its drainage basins between 2000 and 2020. Int. J. Digit. Earth. 2021, 14, 661-677. [CrossRef]

66. Korea Forest Service (KFS). Investigation Report on Korea-Kazakhstan Forestry Cooperation; Korea Forest Service: Daejeon, Korea, 2020. (In Korean)

67. Micklin, P. The Aral Sea Crisis. In Dying and Dead Seas Climatic Versus Anthropic Causes; Nihoul, J.C.J., Zavialov, P.O., Micklin, P.P., Eds.; Springer: Dordrecht, The Netherlands, 2004; pp. 99-123.

68. Huang, Z.; Zhang, X.; Zheng, G.; Gutterman, Y. Influence of light, temperature, salinity and storage on seed germination of Haloxylon ammodendron. J. Arid Environ. 2003, 55, 453-464. [CrossRef]

69. Orlovsky, N.; Birnbaum, E. The role of Haloxylon species for combating desertification in Central Asia. Int. J. Plant Biol. 2002, 136, 233-240.

70. An, J.; Kim, S.; Chang, H.; Khamzina, A.; Son, Y. Vegetation establishment improves topsoil properties and enzyme activities in the dry Aral Sea Bed, Kazakhstan. Forestist 2018, 68, 1-6. [CrossRef]

71. Khamzina, A.; An, J.; Chang, H.; Son, Y. Isotopic signatures as an indicator of long-term water-use efficiency of Haloxylon plantations on the dried Aral Sea Bed. Water 2020, 12, 99. [CrossRef]

72. Chang, H.; An, J.; Khamzina, A.; Lee, W.K.; Son, Y. Growth and carbon storage of black saxaul in afforested areas of the Aralkum Desert. Korean J. Environ. Biol. 2019, 37, 618-624. [CrossRef]

73. Caravaca, F.; Lax, A.; Albaladejo, J. Soil aggregate stability and organic matter in clay and fine silt fractions in urban refuseamended semiarid soils. Soil Sci. Soc. Am. J. 2001, 65, 1235-1238. [CrossRef]

74. Elliott, E.T. Soils with Variable Charge. In Physical and Mechanical Properties of Oxisols; Theng, B.K.G., Ed.; Offset Publications: Palmerston North, New Zealand, 1986; pp. 303-324.

75. Six, J.; Elliott, E.T.; Paustian, K. Soil macroaggregate turnover and microaggregate formation: A mechanism for carbon sequestration under no-tillage agriculture. Soil Biol. Biochem. 2000, 32, 2099-2103. [CrossRef]

76. Löw, F.; Navratil, P.; Kotte, K.; Schöler, H.; Bubenzer, O. Remote-Sensing-Based Analysis of Landscape Change In the Desiccated Seabed of the Aral Sea-A Potential Tool for Assessing the Hazard Degree of Dust and Salt Storms. Environ. Monit. Assess. 2013, 185, 8303-8319. [CrossRef]

77. Qadir, M.; Noble, A.D.; Oster, J.D.; Schubert, S.; Ghafoor, A. Driving forces for sodium removal during phytoremediation of calcareous sodic and saline-sodic soils: A review. Soil Use Manag. 2005, 21, 173-180. [CrossRef]

78. Preece, C.; Peñuelas, J. Rhizodeposition under drought and consequences for soil communities and ecosystem resilience. Plant Soil 2016, 409, 1-17. [CrossRef]

79. Lal, R. Degradation and resilience of soils. Philos. Trans. R. Soc. Lond. B. 1997, 352, 997-1010. [CrossRef] 
80. International Union for Conservation of Nature (IUCN). Global Standard for Nature-Based Solutions. A User-Friendly Framework for the Verification, Design and Scaling Up of NBS, 1st ed.; International Union for Conservation of Nature: Gland, Switzerland, 2020.

81. Monty, F.; Murti, R.; Miththapala, S.; Buyck, C. Ecosystems Protecting Infrastructure and Communities: Lessons Learned and Guidelines for Implementation; International Union for Conservation of Nature: Gland, Switzerland, 2017.

82. Reid, H.; Ali, L. Ecosystem-Based Approaches to Adaptation: Strengthening the Evidence and Informing Policy. Research Results from the Incentive-Based Hilsa Conservation Programme, Bangladesh; International Institute for Environment and Development (IIED): London, UK, 2018. 